\title{
Quantitative Proteomics in Drosophila with Holidic Stable-Isotope Labeling of Amino Acids in Fruit Flies (SILAF)
}

\author{
Florian A. Schober, Ilian Atanassov, Christoph Freyer, \\ and Anna Wredenberg
}

\begin{abstract}
Protein-focused research has been challenging in Drosophila melanogaster due to few specific antibodies for Western blotting and the lack of effective labeling methods for quantitative proteomics. Herein, we describe the preparation of a holidic medium that allows stable-isotope labeling of amino acids in fruit flies (SILAF). Furthermore, in this chapter, we provide a protocol for mitochondrial enrichments from Drosophila larvae and flies together with a procedure to generate high-quality peptides for further analysis by mass spectrometry. Samples obtained following this protocol can be used for various functional studies such as comprehensive proteome profiling or quantitative analysis of posttranslational modifications upon enrichment. SILAF is based on standard fly routines in a basic wet lab environment and provides a flexible and costeffective tool for quantitative protein expression analysis.
\end{abstract}

Key words Drosophila, Proteomics, Stable-isotope labeling, SILAC, Mitochondria

1 Introduction

Stable-isotope labeling of amino acids in cell culture (SILAC) has been a powerful method to quantitatively assess protein content by high-resolution mass spectrometry (MS). In its original application, cells are grown in a medium that contains one or more non-radioactive isotopes of amino acids [1], typically leucine, lysine, and/or arginine. Upon incorporation of a heavy amino acid isotope during translation, a protein gains discrete mass and its peptides can be distinguished from light isotopic counterparts during an MS analysis. This allows the measurement of two or more differently labeled samples at the same time. Although protein quantification in single-shot experiments can now be performed cheaper and easier by label-free quantification, a broad range of experiments are typically performed with or require SILAC, among 
those deep quantitative proteome profiling using fractionation, differential posttranslational modification quantification, immunoprecipitation, and turnover studies [2].

SILAC has been adapted to a range of multicellular models, including worms [3] and mice [4]. For Drosophila melanogaster, the fruit fly, a SILAC method was proposed in 2010 [5] and subsequently developed further $[6,7]$. It relied on labeling of yeast cells with a lysine isotope, which is then fed to flies. To decrease costs and increase labeling efficiency, we developed stable-isotope labeling of amino acids in fruit flies (SILAF) that is based on a holidic medium with purified ingredients $[8,9]$. By replacing "light" L-Lysine- ${ }^{12} \mathrm{C}_{6}$ (lysine-0) with "heavy" L-Lysine- ${ }^{13} \mathrm{C}_{6}$ (lysine-6), we achieve full labeling already at larval stage 2 , which, when combined with peptide fractionation, allows differential quantification of more than 4500 proteins. This is due to the high accuracy of SILAC as samples are combined early on in the experiment. Furthermore, it is possible to measure protein turnover rates in whole adult flies with a labeling pulse. Combined with mitochondrial enrichment, this technique allows deep insights into the mitochondrial fly proteome across a wide dynamic range, comprising nuclear-encoded proteins and mitochondrial-encoded subunits of the oxidative phosphorylation system.

\section{Materials}

\subsection{Yeast Medium}

2.2 Holidic Lysine-0 and Lysine-6 Media
Drosophila are grown on standard yeast medium prior to labeling on holidic food. Media are prepared in deionized water.

1. Stove and a large pot.

2. Plastic tubes, clear, flat bottom.

3. Cotton balls to fit the size of the plastic tubes.

4. Cotton blanket.

5. Gum agar.

6. Sucrose.

7. Powdered yeast.

8. Preservatives: $100 \mathrm{~g} / \mathrm{L}$ methylparaben in $100 \%$ ethanol, propionic acid. Protect from light.

Stock solutions are prepared in purified, deionised water, such as Milli- $Q^{\circledR}$ grade water, if not indicated differently (see Note $\left.\mathbf{1}\right)$. The provided amounts of stock solutions are best for preparations of 
$100 \mathrm{~mL}$ media at a time. All stock solutions should be renewed at least every 3 months.

1. Heating block with shaking function.

2. Autoclave.

3. $100 \mathrm{~mL}$ autoclavable glass bottle with lid.

4. Small stirrer and stirring plate.

5. Plastic tubes, clear, flat bottom, for fly husbandry.

6. Cotton balls to fit the size of the plastic tubes.

7. Syringe filters for sterile filtering.

8. Fine balance with $0.1 \mathrm{mg}$ accuracy.

9. Difco $^{\text {TM }}$ agar.

10. Sucrose.

11. Cholesterol at $20 \mathrm{~g} / \mathrm{L}$ in $100 \%$ ethanol, prepare fresh.

12. Metal ions: $\mathrm{CaCl}_{2} \cdot 6 \mathrm{H}_{2} \mathrm{O}(250 \mathrm{~g} / \mathrm{L})$, anhydrous $\mathrm{MgSO}_{4}$ $(250 \mathrm{~g} / \mathrm{L}), \mathrm{CuSO}_{4} \cdot 5 \mathrm{H}_{2} \mathrm{O}(2.5 \mathrm{~g} / \mathrm{L}), \mathrm{FeSO}_{4} \cdot 7 \mathrm{H}_{2} \mathrm{O}$ $(25 \mathrm{~g} / \mathrm{L}), \mathrm{MnCl}_{2} \cdot 4 \mathrm{H}_{2} \mathrm{O}(\mathrm{l} \mathrm{g} / \mathrm{L}), \mathrm{ZnSO}_{4} \cdot 7 \mathrm{H}_{2} \mathrm{O}(25 \mathrm{~g} / \mathrm{L})$. Aliquot individually $110 \mu \mathrm{L}$ into PCR strips and store at $-20{ }^{\circ} \mathrm{C}$ (see Note 2).

13. Acetate buffer: $3 \%$ acetic acid, $\mathrm{KH}_{2} \mathrm{PO}_{4}(30 \mathrm{~g} / \mathrm{L}), \mathrm{NaHCO}_{3}$ $(10 \mathrm{~g} / \mathrm{L}), \mathrm{pH} 4.0$ ( $s e e$ Notes 3 and 4). Filter sterilize through a syringe filter and store aliquots of $11 \mathrm{~mL}$ at $4{ }^{\circ} \mathrm{C}$.

14. Essential amino acid stock: L-Arginine $(26.92 \mathrm{~g} / \mathrm{L})$, L-Histidine $(10.79 \mathrm{~g} / \mathrm{L})$, L-Methionine $(9.96 \mathrm{~g} / \mathrm{L})$, L-Phenylalanine (16.65 g/L), L-Threonine (18.27 g/L), L-Tryptophan $(5.30 \mathrm{~g} / \mathrm{L}), \mathrm{L}$-Valine $(19.81 \mathrm{~g} / \mathrm{L})$. Titrate to $\mathrm{pH} 4.5$, filter sterilize and store aliquots of $6.5 \mathrm{~mL}$ at $4{ }^{\circ} \mathrm{C}$ ( see Note 5$)$.

15. Nonessential amino acid stock: L-Alanine $(18.18 \mathrm{~g} / \mathrm{L}), \mathrm{L}^{-}$ Asparagine (16.99 g/L,), L-Aspartic acid (19.34 g/L), L-Glutamine $(18.50 \mathrm{~g} / \mathrm{L})$, Glycine $(12.66 \mathrm{~g} / \mathrm{L})$, L-Proline (16.14 g/L), L-Serine $(22.74 \mathrm{~g} / \mathrm{L})$. Titrate to $\mathrm{pH} 4.5$, filter sterilize and store aliquots of $6.5 \mathrm{~mL}$ at $4{ }^{\circ} \mathrm{C}$ ( see Note 5$)$.

16. Vitamin stock: Thiamine $(0.067 \mathrm{~g} / \mathrm{L})$, Riboflavin $(0.033 \mathrm{~g} /$ $\mathrm{L})$, Nicotinic acid $(0.399 \mathrm{~g} / \mathrm{L})$, Calcium pantothenate $(0.516 \mathrm{~g} / \mathrm{L})$, Pyridoxine $(0.083 \mathrm{~g} / \mathrm{L})$, Biotin $(0.007 \mathrm{~g} / \mathrm{L})$. Store aliquots of $2.2 \mathrm{~mL}$ at $-20{ }^{\circ} \mathrm{C}$ away from light.

17. Folic acid solution: folic acid $(0.5 \mathrm{~g} / \mathrm{L})$. Aliquot to $110 \mu \mathrm{L}$ in PCR strips and store at $-20{ }^{\circ} \mathrm{C}($ see Note 6$)$.

18. Nucleic acids/lipids: choline chloride $(6.25 \mathrm{~g} / \mathrm{L})$, myo-inositol $(0.63 \mathrm{~g} / \mathrm{L})$, inosine $(8.13 \mathrm{~g} / \mathrm{L})$, uridine $(7.5 \mathrm{~g} / \mathrm{L})$. Filter sterilize and store aliquots of $750 \mu \mathrm{L}$ at $4{ }^{\circ} \mathrm{C}$.

19. L-Glutamic acid (100 g/L). Filter sterilize and store aliquots of $1.6 \mathrm{~mL}$ at $4{ }^{\circ} \mathrm{C}$. 


\subsection{Mitochondrial Enrichment}

2.4 Peptide Sample Preparation
20. Additional amino acids as powders: L-Isoleucine, L-Leucine, LTyrosine, L-Cysteine.

21. Preservatives: $100 \mathrm{~g} / \mathrm{L}$ methylparaben in $100 \%$ ethanol, propionic acid. Protect from light.

22. Lysine isotopes as powders: L-Lysine- ${ }^{12} \mathrm{C}_{6} \cdot \mathrm{HCL}$ ("light lysine-0"), L-Lysine- $\left[{ }^{13} \mathrm{C}[4 / 6]^{15} \mathrm{~N}[0 / 0]\right]$. HCL ("heavy lysine-6") (see Note 7).

1. Petri dishes.

2. Soft paint brush with about $4 \mathrm{~mm}$ top diameter.

3. Pasteur pipettes.

4. STE buffer: $250 \mathrm{mM}$ Sucrose, $2 \mathrm{mM}$ EGTA, $5 \mathrm{mM}$ Tris. Titrate to $\mathrm{pH} 7.4$ and store at $4{ }^{\circ} \mathrm{C}$ ( see Note 8$)$.

5. Powdered bovine serum albumin (BSA).

6. $2 \mathrm{~mL}$ round-bottom glass homogenizers with tightly fitting Teflon-coated pestle.

7. Electrical homogenizer with adjustable speed.

8. 1.5 and $2.0 \mathrm{~mL}$ protein low-binding tubes.

9. Bench-top high-speed centrifuge with adjustable temperature and fixed-angle rotor for 1.5 and $2 \mathrm{~mL}$ tubes for up to $9000 \times g$.

1. Sterile inoculation needle.

2. Liquid nitrogen.

3. Petri dishes.

4. $6 \mathrm{M}$ guanidine hydrochloride $(\mathrm{GuHCl})$, fresh in $100 \mathrm{mM}$ ammonium bicarbonate, $\mathrm{pH}$ 8.0.

5. Homogenizer and pestles, fitting to the inner shape of a $1.5 \mathrm{~mL}$ tube.

6. Sonicator.

7. Protein quantification assay that has been tested insensitive to $<\mathrm{l} \mathrm{M} \mathrm{GuHCl}$, for example BCA.

8. Dithiothreitol.

9. 2-chloroacetamide, protected from light.

10. $100 \mathrm{mM}$ ammonium bicarbonate, $\mathrm{pH}$ 8.0.

11. Lysyl endopeptidase LysC, MS grade.

12. Formic acid.

13. Disposable $3 \mathrm{~mL}$ cartridges with a C18 disk.

14. Syringe prepared to fit the $3 \mathrm{~mL} \mathrm{C18}$ cartridge (see Note 9). 
15. Methanol.

16. $40 \%$ acetonitrile in water.

17. SpeedVac or similar.

18. NanoDrop ${ }^{\mathrm{TM}}$ spectrophotometer or similar.

3 Methods

\subsection{Preparation of Yeast Medium for Fly Husbandry Prior to Labeling}

\subsection{Preparation of Holidic SILAF Medium}

1. $10 \mathrm{~g}$ of agar are stirred in $1 \mathrm{~L}$ of room temperature deionised water and brought to boil in a large pot.

2. $50 \mathrm{~g}$ of sucrose and $100 \mathrm{~g}$ of yeast powder are added while stirring with a whisk and boiled for $5 \mathrm{~min}$.

3. The liquid medium is allowed to cool down to $40-45^{\circ} \mathrm{C}$. Stir at least once per hour to prevent the yeast from setting.

4. Add $30 \mathrm{~mL}$ methylparaben stock solution and $3 \mathrm{~mL}$ propionic acid to the yeast medium and stir.

5. With a $25 \mathrm{~mL}$ serological pipette, $6 \mathrm{~mL}$ food is dispersed into round, clear, flat-bottom plastic vials. Stir the food in the pot several times while aliquoting. After aliquoting, the filled plastic vials are covered with a cotton blanket and left to solidify overnight.

6. The vials are plugged with cotton balls that fit the size of the vials.

7. Food is stored at $4{ }^{\circ} \mathrm{C}$ for up to 2 weeks.

In order to prepare holidic SILAF medium, take measures to work in a semi-sterile lab environment (see Note 10). A flowchart of the procedure is shown in Fig. la.

1. Thaw one $100 \mu \mathrm{L}$ aliquot of each metal solution $\left(\mathrm{CaCl}_{2}\right.$, $\mathrm{MgSO}_{4}, \mathrm{CuSO}_{4}, \mathrm{FeSO}_{4}, \mathrm{MnCl}_{2}$, and $\left.\mathrm{ZnSO}_{4}\right)$.

2. Prepare $1.5-2 \mathrm{~mL}$ of a $20 \mathrm{mg} / \mathrm{mL}$ cholesterol solution in $100 \%$ ethanol and heat to $50{ }^{\circ} \mathrm{C}$ while shaking at $1000 \mathrm{rpm}$.

3. Measure $69.1 \mathrm{~g}$ of room temperature deionised water in a $100 \mathrm{~mL}$ autoclavable glass bottle with a small magnetic stirrer and mark the top liquid height with a pen on the glass. Decant about $30 \%$ of the water. Place the bottle on a magnetic stirring plate.

4. Add $112 \mathrm{mg}$ L-isoleucine, $203 \mathrm{mg}$ L-leucine, and $93 \mathrm{mg} \mathrm{L}$ tyrosine to the bottle while the stirrer is rotating, as well as $1.71 \mathrm{~g}$ sucrose and $2 \mathrm{~g}$ agar.

5. Add $100 \mu \mathrm{L}$ of each metal solution, as well as $1.5 \mathrm{~mL}$ of cholesterol in ethanol (see Note 11). 
a

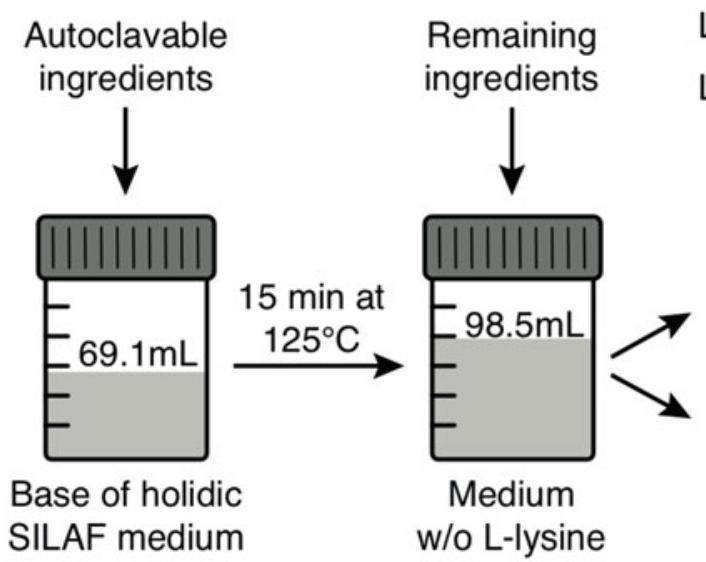

L-lysine-0

L-lysine-6
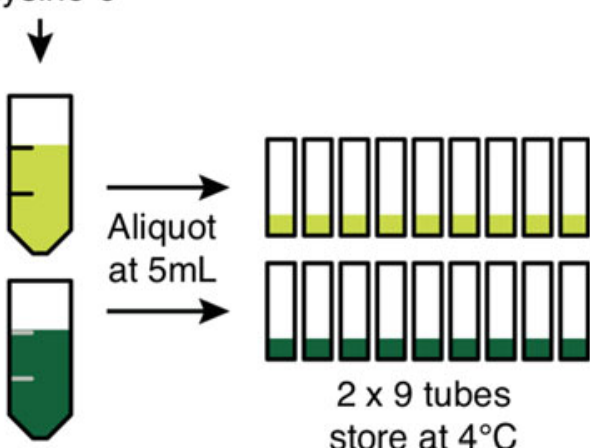
t $5 \mathrm{~mL}$

b
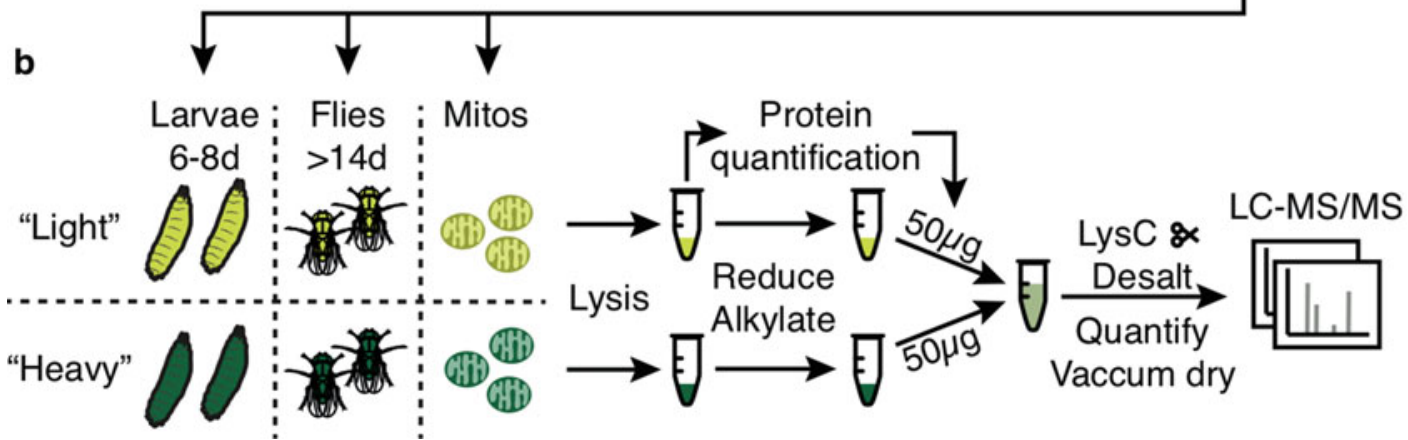

Fig. 1 A typical workflow for (a) the preparation of "light" and "heavy" holidic food and (b) the generation of SILAF peptide samples after larvae or flies have been grown to a fully labeled state from larval stage 2 or mitochondria (mitos) have been enriched

6. Stop stirring and fill the buffer to the mark with room temperature deionized water.

7. Autoclave the food base at $125{ }^{\circ} \mathrm{C}$ for $15 \mathrm{~min}$ after the final pressure has been reached, then switch off the autoclave and wait until the food base is cooled to about $80{ }^{\circ} \mathrm{C}$.

8. In the meanwhile, prepare further required solutions: thaw vitamins and folic acid protected from light; weigh $6.815 \mathrm{mg}$ per $5 \mathrm{~mL}$ of food of lysine- 0 and $8.793 \mathrm{mg}$ per $5 \mathrm{~mL}$ of food of lysine-6, and suspend each in $75 \mu \mathrm{L}$ of deionized water per $5 \mathrm{~mL}$ of food (see Note 12); make a $50 \mathrm{mg} / \mathrm{mL}$ solution of Lcysteine in deionized water.

9. Heat a water bath to $50{ }^{\circ} \mathrm{C}$ with two $50 \mathrm{~mL}$ tubes required for final mixing.

10. Place the $80{ }^{\circ} \mathrm{C}$ warm holidic food base on a stirrer and let it cool to $50-60^{\circ} \mathrm{C}$. Add $10 \mathrm{~mL}$ of acetate buffer (see Note 13 ), $800 \mu \mathrm{L}$ of nucleic acid/lipid solution, $6.05 \mathrm{~mL}$ of essential amino acids and nonessential amino acid solution each, 


\subsection{Fly Husbandry for Quantitative Proteomics}

$1.52 \mathrm{~mL}$ L-glutamate solution, $683 \mu \mathrm{L}$ L-cysteine solution, $2.1 \mathrm{~mL}$ vitamins, $100 \mu \mathrm{L}$ folic acid, $600 \mu \mathrm{L}$ propionic acid, and $1.5 \mathrm{~mL}$ methylparaben solution (see Note 14).

11. Add $75 \mu \mathrm{L}$ per $5 \mathrm{~mL}$ final food volume of lysine- 0 or lysine- 6 to one of the labeled $50 \mathrm{~mL}$ tube in the water bath. Using the graduation, fill up to the required final volume with holidic medium (see Note 15), cap and shake vigorously. Place the tube back in the water bath for 1 min to remove bubbles.

12. Aliquot $5 \mathrm{~mL}$ each into pre-labeled vials. Protect those with a piece of paper tissue and let them cool down for $90 \mathrm{~min}$ to overnight. Plug with cotton balls and store at $4{ }^{\circ} \mathrm{C}$ for up to 1 week (see Note 16).

1. Set the relevant crosses first on yeast medium ( see Note 17). When maximum fecundity is expected, put flies to lay on either light or heavy SILAF medium for the desired amount of time (see Note 18) at a temperature and humidity of choice (see Note 19), typically $25{ }^{\circ} \mathrm{C}$ and $60 \%$ humidity with a $12 / 12$ h light/dark cycle.

2. Grow larvae until at least larval stage 2 to achieve $>95 \%$ to complete labeling (see Note 20) with lysine-6. We typically choose day 7 for collecting larval samples as larvae are not climbing yet but in L3 stage and are labeled close to the lysine-6 purity extent. Flies hatch at 2 weeks after egg lay.

3. Either perform a mitochondrial enrichment as described in Subheading 3.4 or collect samples for whole tissue proteomics. For the latter, pick larvae with a sterile inoculation needle and gloves. Rinse off food remnants in a Petri dish with distilled water and dry larvae with a corner of paper tissue. Anesthetize flies with carbon dioxide. When performing full-body proteomics we prefer to analyze male, nonvirgin flies in order to avoid any bias caused by egg-carrying females. Transfer to a $1.5 \mathrm{~mL}$ low-binding tube, conveniently five to ten insects per tube, snap freeze in liquid nitrogen and store at $-80{ }^{\circ} \mathrm{C}$ until further processing.

Mitochondria are best prepared from larvae as their tissue is softer than flies and thus easier to homogenize. Further, mitochondrial enrichments from flies are more difficult to clean as cuticles and wing fragments tend to float and co-enrich with mitochondria (see Note 21).

1. Solubilize 5\% BSA in STE buffer (STE + BSA buffer), calculating $10 \mathrm{~mL}$ per sample. This buffer should always be freshly prepared.

2. Place the glass homogenizer, an aliquot of STE buffer $(10 \mathrm{~mL}$ per sample), and the STE + BSA buffer in an ice bucket. 
3 . Layer $3 \mathrm{~cm}$ of room temperature, deionized water onto food in vials with larvae and wait for $5 \mathrm{~min}$. Then use a soft paint brush to swirl off larvae from the food. Swirl the tube and pour larvae and liquid into a Petri dish.

4. Pick 10-30 larvae of each label ( see Note 22) with the brush into a precooled, labeled $2 \mathrm{~mL}$ glass homogenizer with $2 \mathrm{~mL}$ of cold STE + BSA buffer (see Note 23). Swirl larvae using the brush and take off most of the liquid with a Pasteur pipette. Subsequently add $1 \mathrm{~mL}$ of cold, fresh STE-BSA.

5. Place a Teflon-coated pestle into the glass vessel and gently homogenize larvae with 14 strokes at $700 \mathrm{rpm}$. Keep cold on ice before, during and after homogenization.

6. Pipette the homogenate into a precooled $2 \mathrm{~mL}$ protein low-binding tube and centrifuge at $1000 \times g$ for $5 \mathrm{~min}$ at $4{ }^{\circ} \mathrm{C}$.

7. Nuclei, not disrupted cells and larger larval fragments will be collected in the pellet at the bottom. Without disrupting this pellet, transfer the supernatant containing mitochondria into a new, cold $1.5 \mathrm{~mL}$ protein low-binding tube. Centrifuge at $3000 \times g$ for $10 \mathrm{~min}$ at $4^{\circ} \mathrm{C}$.

8. Discard the supernatant and gently wash the mitochondrial pellet with $1 \mathrm{~mL}$ of cold STE + BSA ( see Note 24). Centrifuge again at $3000 \times g$ for $10 \mathrm{~min}$ at $4{ }^{\circ} \mathrm{C}$.

9. Discard the supernatant and gently wash the mitochondrial pellet with $1 \mathrm{~mL}$ of cold STE buffer without BSA. Centrifuge at $9000 \times g$ for $5 \mathrm{~min}$ at $4{ }^{\circ} \mathrm{C}$.

10. Discard the supernatant and spin down remaining liquid with a short pulse at $9000 \times g$ and $4{ }^{\circ} \mathrm{C}$. Take of the remaining supernatant with a $10 / 20 \mu \mathrm{L}$ tip and freeze the pellet at $-80{ }^{\circ} \mathrm{C}$.

3.5 Peptide Sample Preparation
We appreciate that there are multiple ways of preparing peptides from frozen samples, including ID SDS-PAGE fractionation and in-gel digestion. For this, a comprehensive pipeline can be found in [10]. We find good protein coverage of mitochondrial, larval and fly samples using the herein provided protocol, sketched in Fig. Ib. The mixing strategy can be modified to fit the experimental needs (see Note 25), below we present the simplest approach.

1. Move samples from $-80{ }^{\circ} \mathrm{C}$ to a room temperature rack and cover with $200 \mu \mathrm{L} 6 \mathrm{M} \mathrm{GuHCl}$ in $100 \mathrm{mM}$ ammonium bicarbonate, $\mathrm{pH}$ 8.0. If working with larvae or flies, then homogenize all samples for about $10 \mathrm{~s}$ with Teflon pestles that fit the conical shape of a $1.5 \mathrm{~mL}$ tube. If working with mitochondria, resuspend the mitochondrial pellet in $\mathrm{GuHCl}$ buffer until it turns clear without any remaining clumps. Incubate samples at room temperature for $10 \mathrm{~min}$. 
2. Sonicate four times at a $10 \mathrm{~s}$ on/off cycle in cold water and incubate for further $10 \mathrm{~min}$ at room temperature.

3. Centrifuge tubes for $5 \mathrm{~min}$ at maximum speed $>10,000 \times g$ for $5 \mathrm{~min}$. Transfer $180 \mu \mathrm{L}$ of supernatant to a new $1.5 \mathrm{~mL}$ low-binding tube. Make sure not to take wings or cuticles when working with flies. If unavoidable, centrifuge again or remove larger particles with a $10 \mu \mathrm{L}$ tip.

4. Dilute $2 \mu \mathrm{L}$ of transferred supernatant in water and quantify with BCA protein assay (see Note 26) so that quantification results can be obtained after $45 \mathrm{~min}$.

5. Reduce the remaining protein-containing supernatant with $9 \mu \mathrm{L}$ of freshly prepared $100 \mathrm{mM}$ dithiothreitol in water for $30 \mathrm{~min}$ at $55{ }^{\circ} \mathrm{C}$ with mild shaking. Place the tube on ice for $10 \mathrm{~s}$ to cool to room temperature, add $10 \mu \mathrm{L}$ of fresh $300 \mathrm{mM}$ 2 -chloroacetamide in water and alkylate at room temperature without light for $15 \mathrm{~min}$.

6. Calculate the volume needed for $50 \mu \mathrm{g}$ of protein in each sample and mix $50 \mu \mathrm{g}$ of each light and heavy fraction in a new $2.0 \mathrm{~mL}$ tube. Fill up to $1.8 \mathrm{~mL}$ with $100 \mathrm{mM}$ ammonium bicarbonate buffer $\mathrm{pH} 8.0$ to reduce the $\mathrm{GuHCl}$ concentration to $<1 \mathrm{M}$. Add 1-2 $\mu \mathrm{g}$ of mass-spectrometry grade lysyl endopeptidase LysC in the manufacturer's recommended resuspension buffer and incubate at $37^{\circ} \mathrm{C}$ overnight for a maximum of $18 \mathrm{~h}$ and mild shaking.

7. Next day, some white precipitates may have formed. Acidify samples by adding $1.2 \%$ formic acid (see Note 27) in a hood and spin at $3000 \times g$ and room temperature for $10 \mathrm{~min}$ to pellet the precipitates.

8. Desalt the supernatant on a $3 \mathrm{~mL}$ cartridge containing a C18 disk according to the manufacturer's recommendations (see Note 28). Typically, we condition the column with $200 \mu \mathrm{L}$ of methanol and equilibrate with $500 \mu \mathrm{L}$ water. The sample is applied and the flowthough is collected in the original tube. Washes include: first wash $1 \mathrm{~mL}$ of acidified sample buffer (100 mM ammonium bicarbonate), second wash $500 \mu \mathrm{L}$ of water, and third wash $500 \mu \mathrm{L} 0.5 \%$ formic acid in water. Peptides are eluted with $300 \mu \mathrm{L} 40 \%$ acetonitrile in water two times by pushing all of the acetonitrile/water solution through the disk into a new $1.5 \mathrm{~mL}$ low-binding tube.

9. The eluate of $600 \mu \mathrm{L}$ is dried in a SpeedVac at room temperature. Be careful to not over-dry the peptide pellets. 
10. Pellets are dissolved in $20 \mu \mathrm{L} 0.5 \%$ formic acid for $10 \mathrm{~min}$ at room temperature and $1 \mu \mathrm{L}$ is quantified on a NanoDrop photospectrometer. The shape of the curve is inspected (see Note 29) and the peptide amount in the remaining $19 \mu \mathrm{L}$ is calculated. An anticipated amount with $100 \mu \mathrm{g}$ of input material for light plus heavy is $20-30 \mu \mathrm{g}$. The solution is dried in a SpeedVac again and stored at $-80{ }^{\circ} \mathrm{C}$ until sent to a proteomics facility on dry ice.

\section{Notes}

1. We use the holidic FLYAA food composition described by Piper et al. [9].

2. $\mathrm{FeSO}_{4}$ oxidizes rapidly in liquid water and precipitates as rust. Freeze quickly and use directly after thawing.

3. Use a vessel much larger than the anticipated amount of buffer and add $\mathrm{NaHCO}_{3}$ slowly to the buffer. $\mathrm{CO}_{2}$ release might make liquid spill.

4. The acetate buffer should reach its $\mathrm{pH}$ after addition of all reagents and we normally do not titrate it. If profoundly off, an ingredient might be wrong or missing.

5. We usually prepare $50 \mathrm{~mL}$ of non-/essential amino acid stocks, which is sufficient for $700 \mathrm{~mL}$ holidic food. Allow sufficient time for weighing and dissolving.

6. Folic acid can require dropwise addition of $1 \mathrm{M} \mathrm{NaOH}$ in order to dissolve.

7. The price of lysine- 6 can be quite high. We found that custom bulk orders of up to $1 \mathrm{mg}$ were usually much cheaper than default prices with a lower price limit of $8 €$ per $99.5 \%$ pure lysine-6 per fly vial of holidic food.

8. A $1 \mathrm{~L}$ stock of STE buffer is most convenient. The $\mathrm{pH}$ of the buffer can be readily adjusted after the initial preparation. Note that the buffer capacity deceases rapidly below 7 and the $\mathrm{pH}$ of 7.4 will have to be re-measured and eventually adjusted before every mitochondrial preparation. Use a $\mathrm{pH}$ meter with a glass electrode and not paper strips as the colorimetric readout would be off by orders of magnitude due to the buffer composition.

9. We use $10 \mathrm{~mL}$ disposable plastic syringes with a smooth-going rubber pestle and two $2.5 \mathrm{~mL}$ tips that are inversely put together and cut in a way to seal the top of a $3 \mathrm{~mL}$ cartridge air-tight. Wash the top of the finished syringe in acetonitrile before use to clean away potential contaminants. 
10. Although it is recommended to work as clean as possible on ethanol-wiped surfaces with previously frozen or filtered substances, a sterile environment is not required to achieve complete incorporation of lysine-6. However, the cooking procedures should be re-evaluated for every other metabolite being changed.

11. The cholesterol tends to precipitate easily on rough surfaces. Either add the $1.5 \mathrm{~mL}$ of cholesterol in ethanol at once with a $<5 \mathrm{~mL}$ serological pipette or change plastic tip while pipetting $2 \times 750 \mu \mathrm{L}$. Add the cholesterol slowly with the tip submerged in liquid. Small clumps of cholesterol might appear after autoclaving, which can be avoided by careful emulsion and constant stirring.

12. Make sure to use the same molar amounts and not weight per volume for both lysine- 0 and lysine- 6 , which is a final of $9.32 \mathrm{mM}$ and a stock of $620 \mathrm{mM}$.

13. The original recipe by Piper et al. [8] suggests to add the acetate buffer before autoclaving. However, the food did not solidify well in our hands. This could be solved by adding the buffer after autoclaving.

14. Add the buffer and amino acid stocks slowly to the still liquid food base as the cold solutions can cause clumping.

15. $100 \mathrm{~mL}$ of food will not be enough for $50 \mathrm{~mL}$ of both light and heavy aliquots. Calculate with maximum $45 \mathrm{~mL}$ instead, i.e., nine tubes each.

16. Vials dry quickly, which is visible by cracks between food and plastic vial. If observed, add one to two drops of water to rehydrate the food.

17. The parent fly generation does not have to be pre-labeled to achieve full incorporation of lysine-6 into the larval L2/L3 proteome.

18. Flies lay well on holidic food. Aim for a medium egg density as too populated vials tend to give smaller larvae that climb ahead of time without pupating. Therefore, monitor the egg density during egg lay every $2 \mathrm{~h}$.

19. Take into account that larvae grow differently on holidic food compared to yeast medium. For instance, climbing of wild-type white Dahomey flies at $25^{\circ} \mathrm{C}$ and $60 \%$ humidity is delayed to 8 days after egg lay compared to standard yeast medium, and hatching occurs after approximately 2 weeks. Furthermore, weak crosses might not be able to develop well on holidic SILAF medium. However, at $18{ }^{\circ} \mathrm{C}$, we found some weak fly stocks to be able to cope better with holidic SILAF medium 
than yeast medium. Precise growth conditions have to be evaluated before the actual experiment on light SILAF medium. We did not observe any developmental and proteomic differences between light and heavy flies.

20. If SILAF is to be established in a Drosophila laboratory, make sure to run tests on incorporation efficiency by picking larvae from only lysine- 6 containing food every 2 days as well as pupae and hatched flies and check the lysine- $6 /$ lysine- 0 ratio by mass spectrometry.

21. If required, mitochondria can also be enriched from adult flies. In that case, start Subheading 3.4 with step 4 and perform step 6 twice. Additionally, we found that a larger tube surface-areato-volume ratio during differential centrifugation as in a $1.5 \mathrm{~mL}$ tube would further help in cleaning the sample.

22. For instance, if control and treated/mutant insects are expected to have the same size and protein content, light and heavy insects can be mixed already at the picking step. The earlier in the process samples are mixed, the more powerful SILAF will be at reducing technical variability.

23. The amount of larvae can be chosen depending on the size of the treated/mutant phenotype so that the amount of control and treated/mutant will be approximately similar at the end of the mitochondrial enrichment.

24. BSA is included in the buffer to reduce the amount of free fat from larvae during mitochondrial enrichment. However, BSA will likely contribute to the most abundant peptide contaminants and it is therefore crucial to wash the mitochondrial pellet at least once with buffer without BSA. When working with flies, which contain less fat than larvae, it is advisable to omit BSA in all steps.

25. Be as gentle as possible while washing the mitochondrial pellet. Do not wash the pellet off the wall directly and try to avoid breaking it at the pipette tip. However, one should obtain an even suspension, which might take up to 2 min per sample.

26. Not all protein assays are suitable for quantifying protein in $\mathrm{GuHCl}$. Perform sensitivity tests on a range of $\mathrm{GuHCl}$ dilutions the first time this protocol is performed. We get sufficient accuracy by diluting the protein solution $1: 10$ in water.

27. The $\mathrm{pH}$ after formic acid addition should be between 2 and 3. It is advisable to test this on $\mathrm{pH}$ paper the first time the experiment is performed. 
28. Make sure to never dry the column and always leave a small amount of liquid on top of the disk. The only exception are the two elution steps, in which acetonitrile in water is completely passed through the disk each time.

29. Expect a high absorption toward UV range and a smaller peak at $280 \mathrm{~nm}$.

\section{Acknowledgements}

This project has received funding from the European Research Council (ERC) under the European Union's Horizon 2020 research and innovation program (grant agreement no. 715009 for AW). AW is supported by the Swedish Research Council (VR2016-02179), the Knut \& Alice Wallenberg Foundation (KAW 2013.0026). IA receives support from the Max Planck Society. FAS is a scholar of the Studienstiftung des deutschen Volkes.

\section{References}

1. Ong S-E, Blagoev B, Kratchmarova I et al (2002) Stable isotope labeling by amino acids in cell culture, SILAC, as a simple and accurate approach to expression proteomics. Mol Cell Proteomics 1:376-386

2. Ong S-E (2012) The expanding field of SILAC. Anal Bioanal Chem 404:967-976

3. Fredens J, Engholm-Keller K, Giessing A et al (2011) Quantitative proteomics by amino acid labeling in C. elegans. Nat Publ Group 8:845-847

4. Krüger M, Moser M, Ussar S et al (2008) SILAC mouse for quantitative proteomics uncovers kindlin-3 as an essential factor for red blood cell function. Cell 134:353-364

5. Sury MD, Chen J-X, Selbach M (2010) The SILAC fly allows for accurate protein quantification in vivo. Mol Cell Proteomics 9:2173-2183

6. Xu P, Tan H, Duong DM et al (2012) Stable isotope labeling with amino acids in drosophila for quantifying proteins and modifications. J Proteome Res 11:4403-4412

7. Chang Y-C, Tang H-W, Liang S-Y et al (2013) Evaluation of drosophila metabolic labeling strategies for in vivo quantitative proteomic analyses with applications to early pupa formation and amino acid starvation. J Proteome Res 12:2138-2150

8. Piper MDW, Blanc E, Leitão-Gonçalves R et al (2014) A holidic medium for Drosophila melanogaster. Nat Publ Group 11:100-105

9. Piper MDW, Soultoukis GA, Blanc E et al (2017) Matching dietary amino acid balance to the in silico-translated exome optimizes growth and reproduction without cost to lifespan. Cell Metab 25:610-621

10. Schmidt C, Urlaub H (2009) iTRAQ-labeling of in-gel digested proteins for relative quantification. In: Proteomics. Humana Press, Totowa, NJ, pp 207-226

Open Access This chapter is licensed under the terms of the Creative Commons Attribution 4.0 International License (http://creativecommons.org/licenses/by/4.0/), which permits use, sharing, adaptation, distribution and reproduction in any medium or format, as long as you give appropriate credit to the original author(s) and the source, provide a link to the Creative Commons license and indicate if changes were made.

The images or other third party material in this chapter are included in the chapter's Creative Commons license, unless indicated otherwise in a credit line to the material. If material is not included in the chapter's Creative Commons license and your intended use is not permitted by statutory regulation or exceeds the permitted use, you will need to obtain permission directly from the copyright holder. 